\title{
Body mass index and blood pressure among adult Bengalee male slum dwellers of Kolkata, India
}

\author{
Raja Chakraborty $\cdot$ Kaushik Bose $\cdot$ Samiran Bisai
}

Published online: 15 May 2009

(C) Springer-Verlag 2009

\section{Erratum to: J Public Health}

\section{DOI 10.1007/s10389-009-0254-9}

The original version of this article unfortunately contained a mistake.

In chapter "Discussion" the 2nd last paragraph should begin with: "Regression analysis also revealed that BMI had a significant positive effect on blood pressures independent of age, MPCI, smoking and alcohol intake status."

The online version of the original article can be found at http://dx.doi. org/10.1007/s10389-009-0254-9.

R. Chakraborty $\cdot \mathrm{K}$. Bose $(\bowtie) \cdot \mathrm{S}$. Bisai

Department of Anthropology, Vidyasagar University,

Midnapore,

721102 West Bengal, India

e-mail: banda@vsnl.net

R. Chakraborty

Department of Anthropology, Dinabandhu Mahavidyalaya,

Bongaon, North 24 Paraganas,

West Bengal, India 